Melisa MARAS ${ }^{1}$

Uniwersytet Kazimierza Wielkiego w Bydgoszczy

\title{
Egzotyzacja i domestykacja w polskim tłumaczeniu powieści „Harry Potter i Kamień Filozoficzny” J. K. Rowling
}

\begin{abstract}
Summary
The aim of the paper is to answer the question what was the Andrzej Polkowski's intent of using domestication and foreignisation strategies in indigenous Harry Potter series translation. Selected fragments of the novel are referring to the widely understood 'food' category and are compared in terms of language and culture. It is known that the Polish translator extends (but does he always domesticate?) the world presented in the novel to the reader's country. However, it is really ambigious, how these extensions affect the interpretation of Polish recipient.
\end{abstract}

Keywords: Harry Potter, foreignization, domestication, translation, food category

\section{Wprowadzenie}

Celem publikacji jest odpowiedź na pytanie, z jaką intencją Andrzej Polkowski użył udomowienia i egzotyzacji w rodzimym tłumaczeniu omawianej serii. Wybrane fragmenty powieści, a dotyczące szerokiej kategorii jedzenia, zostały porównane pod względem językowo-kulturowym. Wiadomo, że polski translator „rozciąga” (ale czy zawsze udomawia?) świat przedstawiony w powieści na kraj czytelnika przekładu. Zastanawiające jest, w jaki sposób działania te wpływają na interpretację polskiego odbiorcy $\mathrm{i}$ to pytanie będzie jednym z głównych zagadnień artykułu.

\section{Egzotyzacja i domestykacja}

Ze względu na to, że użyte w tytule terminy kojarzą się przede wszystkim z dziedziną przekładoznawstwa, należy zaznaczyć, że niniejszy tekst jest analizą dokonaną przez kulturoznawcę i językoznawcę, więc poruszać się będziemy głównie między dwiema dyscyplinami: lingwistyką kulturową oraz translatoryką.

https://orcid.org/0000-0003-4999-8169. 
Wielopłaszczyznowość obu wspomnianych dziedzin sprawia problemy przede wszystkim terminologiczno-metodologiczne. W Polsce znany jest spór między zwolennikami terminów etnolingwistyka i lingwistyka kulturowa². Ta pierwsza, w rozumieniu Jerzego Bartmińskiego, nie tyle powinna być kojarzona z folklorem, ludowością i dialektologią (jak inne dziedziny z przedrostkiem etno(por. Barmiński, 2008: 22)), co z poznaniem „mentalności nosicieli danego języka i kultury" (Bartmiński, 2008: 22). Jednak etnolingwistyka, lingwistyka kulturowa i lingwistyka antropologiczna ${ }^{3}$ składają się z tych samych komponentów: język człowiek (wspólnota ludzka) - kultura, które według różnych klasyfikacji tworzą różne profile (Bartmiński, 2008: 21).

Anna Legeżyńska twierdzi, że „podstawową funkcją tłumaczenia okazuje się pośredniczenie między narodami, epokami i przestrzeniami” (Legeżyńska, 1999: 11). Z kolei „przekład jest wypowiedzą literacką [...] zbudowaną z odmiennego tworzywa językowego i skierowaną do innego czytelnika". Nie można zatem pominąć aspektów kulturowych przy okazji omawiania jakiegokolwiek tłumaczenia. By odpowiedzieć na pytanie, dlaczego tak szczególnie zostają tu podkreślone kwestie językowej obyczajowości, niezbędne jest wyjaśnienie tytułowych pojęć.

Idea egzotyzacji i domestykacji pojawiła się $\mathrm{w}$ badaniach Lawrence'a Venuti'ego, według którego metoda domestykacji (inaczej: udomowienia) to „etnocentryczna redukcja obcojęzycznego tekstu do wartości kulturowych języka docelowego" (Venuti, 1995: 20)4. Inaczej ujmując - udomowienie uprofilowane jest na specyfikę kultury docelowej, a nie oryginału. Z kolei egzotyzacja, według Venuti'ego, to „nacisk na te wartości etniczne, które zarejestrowane w języku oryginału, przedstawiają różnice kulturową obcego tekstu, przenosząc czytelnika za granicę [do kraju pierwopisu - wyj. M. M.]" (Venuti, 1995: 20)5, czyli egzotyzacja to po prostu „strategia przekładowa, która ma na celu zachowanie specyficznych dla kultury źródłowej terminów oraz zachowanie zbliżonej lub

\footnotetext{
2 „Jako poddyscyplina językoznawstwa, ale o korzeniach sięgających różnych dziedzin, lingwistyka kulturowa bada obszary wzajemnego oddziaływania języka, kultury i procesów poznawczych" (Palmer, 1996, Sharifian, 2011, za: Sharifian, 2016: 32).

3 Jerzy Bartmiński stwierdza, że „Najbliższe sobie są terminy etnolingwistyka i lingwistyka antropologiczna, przy czym pierwszy ma tę przewagę, że jest najkrótszy, syntetyzuje wszystkie komponenty [...] i najbardziej sprzyja tworzeniu derywatów (etnolingwista, etnolingwistyczny), z czym są kłopoty przy pozostałych terminach” (Bartmiński, 2008: 21).

4 "domesticating method, an ethnocentric reduction of the foreign text to target-language cultural values, bringing the author back home"[tłum. własne].

5 ,foreignizing method, an ethnodeviant pressure on those values to register the linguistic and cultural difference of the foreign text, sending the reader abroad" [tłum. własne].
} 
identycznej do oryginału formy" (pl.wikipedia.org/wiki/Egzotyzacja_ i_udomowienie, Venuti, 1995).

Jak przekonuje Kaja Wiszniewska-Mazgiel: „konflikt między strategiami stał się problemem kulturowym i politycznym" (Wiszniewska-Mazgiel, 2016: 15)6 Venuti natomiast uważał, że „samo tłumaczenie stanowi akt przemocy”. Według badacza, przekład „wiąże się nie tylko z odtwarzaniem/interpretacją obcych tekstów, ale ma także wpływ na takie obszary, jak dyskryminacja rasowa lub etniczna, konfrontacje polityczne, nawet wojnę" (Venuti, 1993, za: Wiszniewska-Mazgiel, 2016: 15). Venuti sugeruje, że „egzotyzacja stara się powstrzymać [wspomnianą tu już] przemoc tłumaczenia. W dzisiejszych czasach kulturowa interwencja jest wręcz pożądana [...], by przeciwstawić się anglojęzycznej hegemonii i nierównościom kulturowym [...]” (Venuti, 1995: 20)8.

Powyższe słowa są tym bardziej znaczące, że analizując przekład serii J.K. Rowling omawiamy przypadek tłumaczenia z języka angielskiego na język słowiański, a można przecież uznać za aksjomat anglicyzację naszego pokolenia.

\section{Klasyfikacja cyklu powieści o Harrym Potterze}

Cykl powieści o Harrym Potterze J. K. Rowling sklasyfikowany został pierwotnie jako literatura dla dzieci i młodzieży ${ }^{10}$. Według Eweliny Biel i Magdaleny Szumiec „[...] twórcami literatury dla dzieci są ludzie dorośli, którzy za pośrednictwem słowa drukowanego pragną realizować określone funkcje utylitarne” (Biel, Szumiec, 2013). Ta użytkowość może przejawiać się w bardzo różny sposób. Agata

6 "The conflict of strategies became a cultural and political problem" [tłum. własne].

7 “[...]translation itself represents an act of violence" [tłum. własne], (Venuti, 1993, za: WiszniewskaMazgiel, 2016: 15).

8 "I want to suggest that insofar as foreignizing translation seeks to restrain the ethnocentric violence of translation, it is highly desirable today, a strategic cultural intervention in the current state of world affairs, pitched against the hegemonic English-language nations and the unequal cultural exchanges in which they engage their global others" [tłum. własne].

${ }^{9}$ Poradnia językowa IJP UŚ podaje, że słowo „anglicyzacja” jest neologizmem zbudowanym zgodnie z zasadami słowotwórczymi polszczyzny i, mimo że nie ma tego leksemu w „Korpusie języka polskiego PWN", jest to termin potrzebny i oddający znaczenie swoistego przyjmowania i przyswajania kultury angielskiej i języka angielskiego - zgodnie z tradycyjnymi wyrazami, jak „germanizacja” czy „rusyfikacja”.

https://web.facebook.com/por.jez.ijp.us/photos/a.202878433177740.50950.202866873178896/6147160 11993978?_rdc=1\&_rdr [dostęp: 08.10.2017].

10 „Można by więc spróbować opisać Harry’ego Pottera jako cykl utworów zakwalifikowanych przez jego wydawców - oficynę wydawniczą Bloomsbury - do powieści przeznaczonych głównie dla czytelników w średnim wieku szkolnym (9-11 lat), napisanych w konwencji baśniowo-przygodowej" (Kowalewska 2005: 126). 
Brajerska-Mazur zbadała zjawisko manipulizmu w polskim tłumaczeniu Harry'ego Pottera (Brajerska-Mazur, 2015). W swoim artykule badaczka porównuje tłumaczenie, które ulega tak zwanej refrakcji ${ }^{11}$, do promienia światła ulegającego załamaniu: „tak tekst literacki przekształca się w tłumaczeniu pod wpływem różnych mniej lub bardziej widocznych czynników zewnętrznych" (BrajerskaMazur, 2015: 152). Użyteczność omawianej literatury ma tutaj znaczny związek z utylitarnymi funkcjami badanych powyżej strategii tłumaczeniowych. Nie jest przecież tajemnicą, że od zawsze kształcenie najmłodszych pokoleń to nierzadko sprawa polityczna, związana $\mathrm{z}$ wybraną propagandą wyborczą lub poglądami, które zostają, choć często w sposób markowany, ukryty, narzucane młodemu odbiorcy między innymi w kolejnych wydaniach podręczników szkolnych ${ }^{12}$, czy tłumaczeniach wybranych lektur ${ }^{13}$.

Nie wolno jednak zapomnieć, że seria powieści o Harrym Potterze to również literatura fantastyczna ${ }^{14}$, pełna nawiązań do kultury anglosaskiej (zarówno do współczesnej, jak i mitycznej - m.in. celtyckiej). Agata BrajerskaMazur uważa, że: „Polscy czytelnicy fantastyki oczekują technik egzotyzujących, spodziewają się obcych realiów w przedstawianych im światach" (Kowalewska, 2006: 154). Przekładoznawczyni zaznacza, że fani powieści mieli realny wpływ na przekład Andrzeja Polkowskiego ${ }^{15}$. Jako przykład podaje istnienie „krótkiego poradnika dla dociekliwych" i zamieszczone w nim fragmenty, m.in.:

11 Refrakcja według André Lefevere’a to: „adaptowanie dzieł literackich na potrzeby obcej publiczności, dokonywane z zamysłem wywarcia wpływu na sposób, w jaki będą czytane" (Lefevere, 2009: 227, za: Szymańska, bdw: http://www.polisemia.com.pl/numery-czasopisma/numer-2-20102/przeklad-literacki---manipulacja [dostęp: 26.07.2017]).

12 O zjawisku piszą m.in. Zofia Pomirska (Zob. Tejże, Wychowanie ideaologiczne w dawnych podręcznikach do języka polskiego, [w:] „Język-Szkoła-Religia” 7/1, 2012, s. 119-127) czy Agnieszka Rypel (Zob. Tejże, Przestrzeń ideologicznie nacechowana (na przykładzie podręczników języka polskiego), [w:] B. Morzyńska-Wrzosek, D. Mazur (red.), Przestrzeń w kulturze współczesnej. Język, media, architektura. T. 2, Bydgoszcz 2016 - a przede wszystkim Agnieszka Rypel w monografii Ideologiczny wymiar dyskursu edukacyjnego na przykładzie podręczników języka polskiego z lat 1918-2010, Bydgoszcz 2013.

13 Warto zaznaczyć, że cykl powieści o Harrym Potterze nigdy w Polsce nie znalazł się na obowiązkowej liście lektur, prawdopodobnie ze względu na ogromną ambiwalencję recepcji omawianej powieści, co niewątpliwie jest przyczynkiem do osobnych badań. Zjawisko potteromani wskazuje jednak jednoznacznie na fakt popularności książek o młodym czarodzieju i nie ma wątpliwości co do tego, że zarówno dzieci, młodzież, jak i dorośli powieści o Harrym Potterze czytają.

14 Dagmara Kowalewska zauważyła, że widoczne jest „zakorzenienie Harry’ego Pottera w konwencji baśniowej, w tym także mitycznej [...]. Pozostałe gatunki, do których cykl [...] w widoczny sposób nawiązuje, to literatura fantastyczna oraz powieść szkolna” (Kowalewska, 2006: 127).

${ }^{15}$ Andrzej Polkowski - tłumacz siedmiu części powieści o Harrym Potterze J. K. Rowling. 
MAJCHER - imię starego, ale wciąż krwiożerczego buldoga [...] po angielsku Ripper, czyli dosłownie „Rozpruwacz”. [...] Nie można jednak nazwać psa Rozpruwaczem, bo trudno by go było zawołać, więc nadałem mu imię Majcher; wymyśliła je Agnieszka Kowalska z Warszawy, a ja wybrałem je spośród blisko 300 propozycji nadesłanych na konkurs ogłoszony przeze mnie na słynnej już internetowej stronie Harry'ego Pottera (www.harrypotter.prv.pl) redagowanej przez Tytusa Hołdysa (Polkowski, 2012b: 453-454, za: Brajerska-Mazur, 2015: 157-158) [podkreślenie A. B-M].

Poszukiwanie strategii defamiliaryzujących (egzotyzujących) ${ }^{16}$ zdaje się wynikać z potrzeby czytelników literatury fantastycznej, których oczekiwania zostały wspomniane powyżej, bowiem adresaci fantastyki w znacznej większości oczekują, wbrew pozorom, oprócz specyficznego świata przedstawionego (który posiada własne zasady, ale który „rządzi się” nadprzyrodzonymi formami miejsca, czasu i akcji), tradycyjnej formy i konwencji17. Według Anny Brzezińskiej, „fantastyka jest gatunkiem skonwencjonalizowanym, tradycyjnym i popularnym” (Brzezińska, 2009/2010: 6-7), ale jest również poprzez swoją uschematyzowaną formę „atrakcyjna dla czytelnika zmęczonego trudniejszymi w odbiorze współczesnymi arcydziełami powieściowymi” (Tamże) ${ }^{18}$.

\section{Polskie tłumaczenie powieści J. K. Rowling}

Głównym problemem przekładu omawianej powieści jest przede wszystkim liczba neologizmów występujących w utworze ${ }^{19}$. Dodatkowo, istotną barierę stanowią różnice kulturowe między miejscem większości zdarzeń oryginału (Wielką

\footnotetext{
16 Zob. (Fordonski, 2000: 12) [online:] https://www.academia.edu/387926/Egzotyzowa\%C4\%87_defamiliaryzacj\%C4\%99_Problemy_przek \%C5\%82adu_postmodernistycznej_powie\%C5\%9Bci_ameryka\%C5\%84skiej_-_Donald_Barthelme, [dostęp: 25.07.2017].

17 Odpowiadając na możliwy zarzut, że przecież tradycja to jeszcze nie egzotyzacja, pragnę wyjasnić, że tradycyjność fantastyki polega właśnie na zachowywaniu nazw oryginalnych, traktowanie ich jako niezwykłych. Tłumaczenie takich nazw własnych często spotyka się z ogromną krytyką. Przykładem takiej krytyki jest opinia Agnieszki Kobrzyckiej podczas wykładu inaugurującego konferencję „20 lat potteromani, czyli od literatury do popkultury”, która odbyła się 26.05.2017 w Toruniu. Badaczka stwierdziła, że „tłumaczenie [Polkowskiego - M.M.] jest fatalne. Obcięto lub spłycono refleksje filozoficzne, które pojawiają się w grze słów Rowling”. Sądzę jednak, że wybór, jakie nazwy własne przetłumaczyć, jakie „zostawić” lub możliwie zbliżyć do oryginału, nie jest sprawą prostą. Jak pisze Polkowski „Autorzy są świadomi, że nie odkryli wszystkich tajemnych znaczeń słów i ich rodowodów, a w niektórych wypadkach mogli popełnić błędy” (Lipińska, Polkowski, 2008: 6).

18 Tamże.

${ }^{19}$ Siedem tomów polskiego przekładu to prawie 4, 5 tysiąca stron.
} 
Brytanią), a krajami przekładu (tu: Polską). Zastanawiające jest jednak, w jakich sytuacjach tłumacz polskiej wersji językowej użył domestykacji i egzotyzacji $\mathrm{w}$ rodzimym tłumaczeniu serii.

Dowodem swoistej „familiaryzacji” całej fabuły ${ }^{20}$ może być wzmianka Polkowskiego na temat quidditch ${ }^{21}$ we wspomnianym powyżej metatekście: „W Polsce, gdzie ta gra również jest popularna, przyjęła się nazwa angielska, podobnie, jak w wypadku innych sportów, takich jak tenis, rugby czy boks [podkreślenie własne - M. M.]" (Polkowski, 2012a: 361). Według Doroty Guttfeld: „Opis ten sugeruje, że w Polsce także istnieją kluby sportowe czarodziejów, że i tu również muszą żyć w ukryciu przedstawiciele świata magicznego - świata, który wobec tego rozciąga się również na kraj czytelnika przekładu [podkreślenia - M. M.]" (Guttfeld, 2012: 90).

Polkowski stwierdził, że najwięcej problemów z tłumaczeniem przysporzyły $\mathrm{mu}$ przeróżne angielskie potrawy ${ }^{22}$. Analizując oba teksty (brytyjskii ${ }^{23}$ i polski), faktycznie moją uwagę przykuły przede wszystkim nazwy artykułów spożywczych lub rzeczy $\mathrm{z}$ nimi związanych. Wzbudzają one ogrom emocji, ponieważ poszczególne tłumaczenia często zmieniają dla czytelnika powieści kontekst. Mimo że starałam się poddać teksty rzetelnej analizie, nie bez znaczenia pozostaje fakt, iż czas mojego dzieciństwa przypadł na lata 90. XX wieku - i kolejne skojarzenia z polską kuchnią będą tego dowodem²4.

20 Jako familiaryzację fabuły rozumiem chęć przybliżenia sytuacji najbliższej oryginałowi, którą jednak będzie mógł odczytać według siebie i swojej kultury czytelnik języka docelowego. Polkowski powiedział, że sprawą dla niego najważniejszą jest ,jak najlepsze oddanie tego, co chciał powiedzieć autor, a nie co aktualnie powiedział w swoim rodzimym języku. [...] zawsze bardziej chodzi o wizje i odczucia, które świadomie chciał wywołać w czytelniku autor. Dlatego, moim zadaniem jest doprowadzenie polskiego przekładu do sytuacji najbliższej tej, w jakiej znajduje się angielskojęzyczny czytelnik oryginału”. A. Polkowski w rozmowie z Dominiką Pycińską, Siła kruchego słowa, „Miesięcznik ZNAK”, wrzesień 2010, nr 665, [online:] http://www.miesiecznik.znak.com.pl/ 6642010zandrzejem-polkowskim-rozmawia-dominika-pycinskasila-kruchego-slowa/, [dostęp: 08.10.2017].

${ }^{21}$ Quidditch to ulubiona gra czarodziejów w cyklu powieściowym o Harrym Potterze. Zob. hasło 'quidditch' (Lipińska, Polkowski, 2008: 278-288; Rowling, 2017: 278-288).

${ }^{22} \mathrm{~W}$ jednym z wywiadów Polkowski zapytany o to, co sprawiało mu największą trudność podczas tłumaczenia cyklu o Harrym Potterze, odpowiedział: „[...] Szczególnie trudno było przy nazwach potraw. Zwłaszcza jeśli ich nigdy nie jadłem ani nawet nie widziałem. Nawet internet nie zawsze mógł pomóc, a słodkie ciasta i ciasteczka, od których uginają się książkowe stoły, były prawdziwą zmorą" A. Polkowski w rozmowie z Chrystianem Orzeszko, http://www.emetro.pl/emetro/ 1,85648,4875002.html, [dostęp: 14.10.2017]

${ }^{23}$ Należy pamiętać, że istnieje rozróżnienie języka angielskiego m.in. na brytyjski i amerykański. Porównanie brytyjskiej i amerykańskiej edycji omawianej powieści można znaleźć tu: http://helenajole.freeservers.com/home/Harry.html [dostęp: 16.08.2017].

${ }_{24}$ Bardzo ciekawe jest zbadanie, czy dla starszego/młodszego czytelnika powieści, te same potrawy $\mathrm{i}$ ich tłumaczenia będą miały takie same odniesienia. 
Jednym $\mathrm{z}$ ciekawych przykładów ingerencji tłumacza $\mathrm{w}$ omawianym tekście ${ }^{25}$ jest zdanie: Every year on Dudley's birthday his parents took him and a friend out for the day, to adventure, parks, hamburger bars or the cinema (Rowling, 1998: 22), przetłumaczone na: $W$ każde urodziny rodzice zabierali Dudleya $i$ któregoś z jego kolegów na cały dzień do miasta, do wesołego miasteczka, McDonalda albo do kina (Rowling, 2012: 27).

$\mathrm{W}$ pokazanym tłumaczeniu widać różnicę $\mathrm{w}$ rozrywkach, jakie ponoć zapewniają synowi państwo Dursley. $\mathrm{O}$ ile $\mathrm{w}$ oryginale są to: przygody (w znaczeniu jakiejś ekscytującej rozrywki, często wymagającej odwagi), parki, bary z hamburgerami (hamburgerownie) i kina, w polskiej wersji językowej mamy do czynienia z: wesołym miasteczkiem, McDonaldem i kinem. Jedynie kino pokrywa się z angielskojęzyczną wersją. Dlaczego więc Polkowski zdecydował się na wesołe miasteczko i McDonalda? Prawdopodobnie dlatego, że w Polsce przyjazd wesołego miasteczka do miasta albo wizyta w McDonaldzie przez ostatnie dziecięciolecia była niezwykłym wydarzeniem. O ile teraz McDonald nie jest już jedyną znaną marką fast foodów, to nie zapominajmy, że Harry Potter i Kamień Filozoficzny pojawił się w Polsce po raz pierwszy w 2000 roku, czyli prawie 20 lat temu. Sieć McDonald's była wtedy symbolem, wręcz uosobieniem barów szybkiej obsługi w Polsce, a przyjezdne wesołe miasteczka i cyrki jeszcze 15 lat temu były rozrywką na weekend dla całego miasta ${ }^{26}$. Można więc ten przykład tłumaczenia wziąć za domestykację. Harry Potter mógł czuć „tęsknotę” za adventure, parks, hamburger bars, ale które polskie dziecko (w 2000 roku) nie zazdrościłoby urodzin $\mathrm{w}$ wesołym miasteczku i McDonaldzie ${ }^{27}$ ? Co więcej, park rozrywki wiąże się często z ekscytującą zabawą, co pasuje do koncepcji rozrywki $\mathrm{z}$ oryginału.

Wiele interesujących przykładów domestykacji znajdujemy w tłumaczeniu artykułów spożywczych, na przykład gdy Dudley rozrzuca po ścianach his cereal (Rowling, 1998: 8), w polskiej wersji czytamy o owsiance (Rowling, 2012: 6), a tymczasem angielski rzeczownik cereals oznacza płatki śniadaniowe. Poza tym

\footnotetext{
${ }^{25}$ Zdecydowałam się na analizę zaledwie fragmentów pierwszej, najmniej obszernej części - ze względów praktycznych.

${ }^{26}$ Różnice w wyborze rozrywki istnieją przez ogromny wzrost dostępności różnorodnych form spędzania wolnego czasu. Dwie dekady temu nie było tak ogólnego dostępu (o ile był w ogóle) do np.: jumping parków, escape roomów, aqua parków, lotów paralotnią, ścianek wspinaczkowych dla dzieci, laser fightów i innych interaktywnych, popularnych teraz rozrywek.

${ }^{27}$ Możliwe, że Polkowski zdecydował się na taką formę tłumaczenia ze względu na małą popularność leksemów hamburgerownia i bar z hamburgerami w potocznym języku polskim - w Narodowym Korpusie Języka Polskiego hamburgerownia pojawia się zaledwie pięć razy (!). Znaleźć można jednak jedno użycie tego słowa już w 1992 roku.
} 
leksem cereal jest źródłem dodatkowych wątpliwości w tłumaczeniu - może odnosić się do zboża lub płatków zbożowych. I o ile owsianka to po prostu płatki owsiane lub zupa z tych płatków, najczęściej z wodą lub mlekiem, po angielsku danie to ma zupełnie inną nazwę - porridge lub oatmeal. Dlaczego Polkowski zdecydował się na zamianę płatków zbożowych na owsiankę? Można uznać to za przykład swoistego udomowienia, jeśli weźmiemy pod uwagę, że owsianką nazywana jest również rodzima zupa mleczna. Potrawa ta kojarzy się z jednym $\mathrm{z}$ podstawowych dań $\mathrm{w}$ barach mlecznych ${ }^{28}$ - znana $\mathrm{w}$ przeróżnych wersjach m.in.: z chlebem, makaronem, lanymi kluskami, kaszą manną czy z płatkami owsianymi (tzw. „owsianką”) ${ }^{29}$. Zupa mleczna była też w Polsce sztandarowym daniem śniadaniowym przez lata.

Można zatem skonstatować, że rozrzucanie owsianki (a nie samych płatków) po ścianach przez Dudleya mocniej oddziałuje na polskiego czytelnika. Ponadto jeśli już mowa o wpływach - nie jest tajemnicą, że kuchnia brudna od zupy mlecznej i owsianych płatków to większy problem, niż porozrzucane suche płatki śniadaniowe. Tak postawiona sprawa stawia syna państwa Dursley w jeszcze gorszym świetle.

Z drugiej jednak strony omawiana „owsianka” może kojarzyć się z kulturą angielską. Jak pisze jeden z blogerów: „Nawet nie przypuszczałem, że to niewyszukane danie, postawi mnie w gronie celebrytów - premiera Wielkiej Brytanii Davida Camerona i znanej modelki Kate Moss. Oni także swój dzień zaczynają od otrębów owsianych. Teraz musli, czy płatki kukurydziane są passé. W Londynie na śniadanie jada się porridge" (http://zmywak.blox.pl/2010/11/ Londyn-szaleje-na-punkcie-owsianki.html). Takie podejście (skojarzenie $\mathrm{z}$ anglosaską kulturą jedzenia) mogłoby wskazywać na egzotyzujące podejście do kwesti owsianki.

Czy można więc uznać, że Polkowski rozmyślnie poszukuje językowokulturowych symboli, by zarówno przybliżyć (udomowić), jak i zdefamiliaryzować świat przedstawiony w powieści?

Kiedy w angielskiej wersji językowej pan Dursley idzie kupić a bun from the baker's opposite, a potem niesie large doughnut in a bag (Rowling, 1998: 9)

\footnotetext{
${ }^{28}$ Bar mleczny - polski rodzaj baru szybkiej obsługi oparty na kuchni tradycyjnej. Warto zwrócić uwagę na nazwę tego baru w omawianym kontekście (prawdopodobnie pochodzącej od rodzajów serwowanych dań). Więcej na temat historii barów mlecznych: http://superbiz.se.pl/firma/historiabarow-mlecznych-w-polsce-galeria_905107.html; http://niewinni-czarodzieje.pl/bar-mleczny-jakozjawisko-kulturowe; https://pl.wikipedia.org/wiki/Bar_mleczny [dostęp do wszystkich stron wymienionych w przypisie: 16.08 .2017$]$.

29 Por. 1) https://pl.wikipedia.org/wiki/Zupa_mleczna [dostęp: 16.08.2017], 2) http://matkatylkojedna.pl/ kto-jeszcze-zjada-zupy-mleczne-czyli-sposob-na-lane-kluski/ [dostęp: 16.08.2017].
} 
- w polskiej wersji - pan Dursley rusza, by kupić sobie bułkę z rodzynkami, a wychodzi ze sklepu $z$ wielkim kawałem ciasta $z$ orzechami (Rowling, 2012: 8). Bun czyli po prostu słodka bułka (często zawierająca suszone owoce), bardzo popularna w Wielkiej Brytanii - zastąpiona została bułką z rodzynkami. W pierwszej chwili mogłoby się wydawać, że jest to element egzotyzujący, ponieważ kto w Polsce idzie do piekarni po bułkę z rodzynkami? Najczęściej idziemy do piekarni po drożdźówkę albo „po coś do kawy”. Po chwili zastanowienia jednak okazuje się, że znana jest nam słodka bułka - zarówno w wersji sauté, jak i z owocami, posypką lub kruszonką.

Ponownie można zauważyć, że to tłumaczenie miało w pewnym sensie przybliżyć polskiemu czytelnikowi sytuację oryginału. Gdyby pan Dursley zechciał wybrać się po prostu po słodką bułkę, brzmiałoby to dosyć niecodziennie - a należy pamiętać, że rodzina Dursleyów chciała być uznawana za całkowicie normalną.

Większego problemu przysparza jednak wielki kawał ciasta z orzechami, ponieważ doughnat ${ }^{30}$ to nic innego jak po prostu pączek (najpopularniejszy doughnat jest z dziurką w środku). Nie potrafię znaleźć wyjaśnienia dla zamiany znanego nam przecież pączka na ciasto $\mathrm{z}$ orzechami. Chociaż może być to swoisty rodzaj udomowienia. Kiedy Amerykanie (por. przypis 30) zajadają się pączkami z Dunkin' Donuts, my przecież wracamy ze sklepu „z ciastem do kawy”, a objadanie się pączkami w Polsce konotuje raczej zwyczaje związane z Tłustym Czwartkiem ${ }^{31}$ niż zwykłym dniem zwykłego pracownika, którego reprezentował $\mathrm{z}$ całą pewnością pan Vernon Dursley.

\section{Wnioski}

Przytoczone fragmenty to jedynie niewielka ilość przykładów na pojawienie się udomowień i egzotyzacji w polskiej wersji językowej powieści o młodym czarodzieju. Tak mała próbka jest zaledwie przyczynkiem do szerszych badań na wspomniany temat.

\footnotetext{
30 Rozpowszechniona na świecie i w Polsce nazwa to amerykański odpowiednik: donut. Możliwe, że przez prostszą pisownię. Warto zaznaczyć, że najbardziej znaną siecią barów, która specjalizuje się w produkcji wspomnianych pączków jest Dunkin' Donuts (Zob. http://www.dunkindonutspoland. com/). W Stanach Zjednoczonych Ameryki to pączki z Dunkin' Donuts leżą w pokoju nauczycielskim z okazji wybranego święta lub u szefa w gabinecie - zamiast na przykład rodzimego „ciasta”.

31 Ciekawą genezę Tłustego Czwartku oraz zwyczaju jedzenia w ten dzień pączków, faworków i innych przysmaków można przeczytać na stronie: https://historiamniejznanaizapomniana. wordpress.com/2016/02/04/historia-tlustego-czwartku/ [dostęp: 18.10.2017].
} 
Analiza wyekscerpowanego materiału dowiodła, że tłumacz cyklu o młodym czarodzieju łączy obie omawiane techniki tłumaczeniowe. Jest to $\mathrm{w}$ pewnym sensie filozofia złotego środka, którą Polkowski zdaje się kierować. Translator charakteryzuje się dbałością o szczegóły, szacunkiem do autora i czytelnika, co potwierdzają nie tylko jego tłumaczenia, ale również wypowiedzi. Sprawca polskiego tłumaczenia cyklu o Harrym Potterze jest jego swoistym „drugim autorem” (por. Legeżyńska, 1999: 11) i współtwórcą powieści o Harrym Potterze, które znamy w Polsce. Zapytany, co właściwie zafascynowało go w omawianej serii, powiedział:

„[...] zrozumiałem przede wszystkim, że dzieci i młodzież w Anglii i w Stanach opanowało jakieś szaleństwo na punkcie tej książki, że czegoś takiego jeszcze nigdy nie było. A ponieważ mam duże zaufanie do dzieci i młodzieży, chciałem się dowiedzieć, co w tej książce jest takiego, co to szaleństwo wywołało" (http://www.prorok.pl/potter/art-109,0.html).

Jak twierdzi Julia Ecclashare, tom Harry Potter i Kamień Filozoficzny na pierwszy rzut oka wydaje się być przewidywalny, ma prostą fabułę (opartą na stereotypicznej budowie charakterów, włączając w to główną postać, Harry’ego sierotę - która staje ponad przeciwnościami losu, by stać się bohaterem) (por. Ecclashare, 2002: 20). Jednak już w trakcie analizy lektury okazuje się, iż nie dosyć, że powieść jest synkretyczna gatunkowo, niesie ze sobą również szerokie przesłania kulturowe. Wracając do spostrzeżenia Legeżyńskiej: translacja jest swoistego rodzaju pośrednikiem między narodami i przestrzeniami (zob. Legeżyńska, 1999: 11). Tłumaczenie powieści Rowling przez Polkowskiego zdaje egzamin na internacjonalnego mediatora - nawet w trakcie badania pojedynczych zdań $^{32}$. Tłumacz polskiej wersji językowej łączy szacunek do przestrzeni, w jakiej została osadzona oryginalna treść, z respektem wobec odbiorcy, który znajduje się w innej rzeczywistości kulturowej.

\section{Bibliografia}

\section{Literatura podmiotu:}

Rowling J. K. (1998). Harry Potter and the Philosopher's Stone, London: Bloomsbury.

Rowling J. K. (2012). Harry Potter i Kamień Filozoficzny, tłum. Andrzej Polkowski, Poznań: Media Rodzina.

\footnotetext{
${ }^{32} \mathrm{Na}$ pierwszy rzut oka może się wydawać, że analizowane powyżej zdania nie mają większego znaczenia dla fabuły powieści, ale osadzają jej treść w pewnym kontekście kulturowym, którego nie sposób ominąć w trakcie percepcji lektury.
} 
Rowling J. K. (2017). Quidditch przez wieki, tłum. Andrzej Polkowski, Poznań: Media Rodzina.

Literatura przedmiotu:

Bartmiński J. (2008). „Etnolingwistyka, lingwistyka kulturowa, lingwistyka antropologiczna?", Język a Kultura, Tom 20, Wrocław: Wyd. Uniwersytet Wrocławski.

Eccleshare J. (2002). A guide to the Harry Potter novels, London - New York: continuum.

Guttfeld D. (2012). Elementy kulturowe w nagielsko-polskich przekładach science-fiction i fantasy, Torun: Wyd. Naukowe Uniwersytetu Mikołaja Kopernika.

Kowalewska D. (2006). Harry i czary-mary, czyli o wartościach edukacyjnych w cyklu powieści „Harry Potter" J.K. Rowling”, Kraków: Towarzystwo Autorów i Wydawców Prac Naukowych Universitas.

Legeżyńska A. (1999). Tłumacz i jego kompetencje autorskie, Warszawa: Wyd. Naukowe PWN.

Lipińska J., Polkowski A. (2008). Tezaurus I-VII, Warszawa: Wyd. W. Cejrowski Ltd.

Polkowski A. (2012a). Kilka słów od tłumacza, czyli krótki poradnik dla dociekliwych, [w:] Rowling J. K., Harry Potter i Komnata Tajemnic, tłum. A. Polkowski, Poznań: Media Rodzina.

Polkowski A. (2012b). Kilka słów od tłumacza, czyli krótki poradnik dla dociekliwych, [w:] Rowling J. K., Harry Potter i Więzień Azkabanu, tłum. A. Polkowski, Poznań: Media Rodzina.

Pomirska Z. (2012). Wychowanie ideologiczne w dawnych podręcznikach do języka polskiego, [w:] „Język-Szkoła-Religia" 7/1.

Rypel A. (2016). "Przestrzeń ideologicznie nacechowana (na przykładzie podręczników języka polskiego)", [w:] Przestrzeń w kulturze współczesnej. Język, media, architektura. T. 2, Morzyńska-Wrzosek B., Mazur D. (red.), Bydgoszcz: Wydawnictwo Uniwersytetu Kazimierza Wielkiego.

Venuti L. (2010). "Translation as Cultural Politics: Regimes of Domestication in English, [w:] Baker M., Critical Readings in Translation Studies, London: Routledge.

Venuti L. (1995). The Translator's Invisibility, London-New York: Routledge.

Wiszniewska-Mazgiel K. (2016). Non-fiction in translation: "Modern Romance" by Azis Ansari, niepublikowana praca magisterska, Gdańsk: Uniwersytet Gdański [komputeropis].

Withlam G. (2014). "Revelio! A (socio-)semiotic reading of the Harry Potter saga", [w:] New Semiotics. Between Tradition and Innovation, Sofia.

\section{Netografia:}

Auriacombe É. (2016). "Harry Potter et l'expérience d'effroi: l'effet des Détraqueurs", [w:] Romanica Silesiana 11/1, [online:] http://bazhum.muzhp.pl/media//files/Romanica_ Silesiana/Romanica_Silesiana-r2016-t11-n1/Romanica_Silesiana-r2016-t11-n1-s106115/Romanica_Silesiana-r2016-t11-n1-s106-115.pdf [dostęp: 25.07.2017]. 
Biel E., Szumiec M. (2013). Harry Potter jako wzrór do naśladowania współczesnych dzieci i młodzieży, [online:]

Brajerska-Mazur A. (2015). "Manipulizm a wpływ czytelników na polskie tłumaczenie „Harry'ego Pottera”, [w:] Roczniki Humanistyczne 63/2015, [online:] https://www.ceeol.com/search/article-detail?id=341940 [dostęp: 25.07.2017].

Brzezińska A. (2017). Dlaczego czytelnicy kochają fantastykę?, [w:] „Ryms” nr 8, 2009/2010, s.6-7, [online:] http://ryms.pl/artykul_szczegoly/49/dlaczego-czytelnicykochaja-fantastyke.html, [dostęp: 26.07.2017].

Fordonski K. (2000). "Egzotyzować defamiliaryzację? Problemy przekładu postmodernistycznej powieści amerykańskiej - Donald Barthelme”, [w:] Przekładając nieprzekładalne. Materiały z I Międzynarodowej Konferencji Translatorycznej Gdańsk-Elbląg, Kubiński W., Kubińska O., Wolański T. Z. (red.), Przekładając nieprzekładalne. Materiały z I Międzynarodowej Konferencji Translatorycznej Gdańsk-Elbląg, Gdańsk [online:] https://www.academia.edu/387926/ Egzotyzowa\%C4\%87_defamiliaryzacj\%C4\%99_Problemy_przek\%C5\%82adu_post modernistycznej_powie\%C5\%9Bci_ameryka\%C5\%84skiej_-_Donald_Barthelme, [dostęp: 25.07.2017].

http://helenajole.freeservers.com/home/Harry.html [dostęp: 21.04.2017].

http://matkatylkojedna.pl/kto-jeszcze-zjada-zupy-mleczne-czyli-sposob-na-lane-kluski/ [dostęp: 21.04.2017].

http://niewinni-czarodzieje.pl/bar-mleczny-jako-zjawisko-kulturowe; [dostęp: 21.04.2017]. http://rep.up.krakow.pl/xmlui/bitstream/handle/11716/927/harry_potter_jako_wzor_do_na slad_biel_ewelina_szumiec_000041.pdf?sequence=1 [dostęp: 25.07.2017].

http://superbiz.se.pl/firma/historia-barow-mlecznych-w-polsce-galeria_905107.html; [dostęp: 19.04.2017].

http://www.dunkindonutspoland.com/ [dostęp: 19.04.2017].

http://www.emetro.pl/emetro/1,85648,4875002.html, [dostęp: 19.04.2017].

http://www.prorok.pl/potter/art-109,0.html, [dostęp: 19.04.2017].

http://zmywak.blox.pl/2010/11/Londyn-szaleje-na-punkcie-owsianki.html [dostęp: 07.10.2017].

https://historiamniejznanaizapomniana.wordpress.com/2016/02/04/historia-tlustegoczwartku/

https://pl.wikipedia.org/wiki/Bar_mleczny

https://pl.wikipedia.org/wiki/Egzotyzacja_i_udomowienie [dostęp: 20.07.2017].

https://pl.wikipedia.org/wiki/Zupa_mleczna, [dostęp: 19.04.2017].

https://web.facebook.com/por.jez.ijp.us/photos/a.202878433177740.50950.20286687317889 6/614716011993978?_rdc=1\&_rdr

https://www.academia.edu/387926/Egzotyzowa\%C4\%87_defamiliaryzacj\%C4\%99_Proble my_przek\%C5\%82adu_postmodernistycznej_powie\%C5\%9Bci_ameryka\%C5\%84sk iej_-_Donald_Barthelme, [dostęp: 25.07.2017].

Lefevere A. (2009). „Ogórki Matki Courage”, przeł. A. Sadza, [w:] Współczesne teorie przekładu. Antologia, red. P. Bukowski, M. Heydel, Kraków, [za:] Katarzyna 
Szymańska, Przekład Literacki - manipulacja: refrakcja i instytucja patronatu wedhug André Lefevre’a i Manipulation School, [w:] „Polisemia. Czasopismo Naukowe Antropologów Literatury Uniwersytetu Jagiellońskiego”, [online:] http://www.polisemia.com.pl/numery-czasopisma/numer-2-2010-2/przekladliteracki---manipulacja, [dostęp: 26.07.2017].

Masroor F., Pourmohammadi M. (2016). "Problems In Translating Figures of Speech: A Review of Persian Translations of Harry Potter Series", [w:] International Journal of English Language \& Translations Studies 4(4), b. m. w. [online:] http://www.eltsjournal.org/archive/value4\%20issue4/12-4-4-16.pdf [dostęp: 12.11.2017].

Minér M., Beyond Foreignisation and Domestication, Harry Potter in Hungarian Translation, [online:] https://www.academia.edu/8123728/_Beyond_Foreignisation_ and_Domestication_Harry_Potter_in_Hungarian_Translation_[dostęp: 20.07.2017].

Narodowy Korpus Języka Polskiego, red. Mirosław Bańsko i in., [online:] http://nkjp.pl/ [dostęp: 22.10.2017].

Polkowski A. w rozmowie z Dominiką Pycińską, Siła kruchego słowa, „Miesięcznik ZNAK”, wrzesień 2010, nr 665, [online:] http://www.miesiecznik.znak.com.pl/ 6642010z-andrzejem-polkowskim-rozmawia-dominika-pycinskasila-kruchegoslowa/, [dostęp: 08.10.2017].

Sharifian Farzad, "Lingwistyka kulturowa [Cultural linguistics]", [w:] Etnolingwistyka 28, Lublin 2016, [online:] https://journals.umcs.pl/et/article/download/2269/pdf, [dostęp: 01.12.2017].

Tee C.G., In Defense of Schleiermacher: A Critique of Venuti's Foreignization and Domestication, [online:] https:/www.academia.edu/22493383/In_Defense_of_ Schleiermacher_A_Critique_of_Venutis_Foreignization_and_Domestication [dostęp: 25.07.2017]. 
